\section{LA POLÍTICA SANITARIA DEL PERONISMO}

\section{DIEGO ORTÚZAR ${ }^{(1)}$}

Ramacciotti, Karina. Buenos Aires: Biblos; 2009, 187 p. ISBN 978-950-786-768-2, US\$ 12,43

\section{RESUMEN}

El libro de la historiadora Karina Ramacciotti, doctora en Ciencias Sociales de la Universidad de Buenos Aires, da cuenta de la formación y contingencias políticas del sistema sanitario de la Argentina durante el peronismo (1946-1955). Dicho período es abordado a propósito de la puesta en marcha de un proyecto sanitario que promete ser universal, de escala nacional y financiado con recursos públicos, en un contexto de políticas centradas en el reconocimiento de los derechos sociales y en discursos de justicia social.

Palabras clave: Salud, Argentina, peronismo, política.

Para comprender los derroteros de la política sanitaria del peronismo, la autora se desmarca de la figura del presidente Juan Domingo Perón e introduce acontecimientos históricos diversos, tales como las tendencias higienistas de fines del s. XIX, las crisis económicas, los brotes epidémicos, los conflictos institucionales, entre otros. El resultado es una visión compleja y dinámica de los acontecimientos sanitarios del peronismo.

En cuanto a la organización, el libro atraviesa un primer período (1946-1950) político sanitario que se caracteriza por la expansión de centros hospitalarios y la implementación de estrategias sanitarias a nivel nacional dirigidas por la Secretaría de Salud Pública. Un segundo período (1950-1954) abarca la transformación de dicha Secretaría en un Mi- nisterio de Salud Pública, en un contexto de importantes restricciones presupuestarias $\mathrm{y}$ disputas institucionales.

Otro plano de la narración es la historia de Ramón Carrillo, hombre de confianza del coronel y futuro presidente Perón. Su carrera como médico y su quehacer político como líder de la Secretaría de Salud (1946) y luego ministro del primer Ministerio de Salud de la Argentina (1949), permite abordar las transformaciones del ámbito sanitario y desarrollar, en seis capítulos, la complejidad de los procesos sociales y económicos que coinciden en su trayectoria.

El primer capítulo aborda las tentativas de centralización del aparato gubernamental sanitario desde fines del siglo XIX, considerando elementos diversos tales como las demandas del movimiento obrero, los brotes de enfermedades infecciosas y epidémicas, la naciente legislación social y la represión política de las primeras décadas del siglo XX. Dichos antecedentes desembocan en la llegada al poder de Juan Domingo Perón (1946) y la creación de la Secretaría de Salud Pública, institución que materializar la planificación e intervención a nivel nacional.

El segundo capítulo aborda la trayectoria académica, política y social de Ramón Carrillo. La autora se detiene en su desempeño como médico y académico de la Facultad de Ciencias Médicas de la Universidad de Buenos Aires, en sus alianzas con nacionalistas de derecha y grupos castrenses, y en su rol como líder de la Secretaría de Salud Pública y luego primer Ministro de Salud de la Argentina.

El tercer capítulo estudia la institucionalización de la salud pública en Argentina. Se centra en la transformación de la Secretaría de Salud en Ministerio de Salud, en el crecimiento del aparato burocrático necesario para sostener la centralización, y en los obstáculos financieros que dicho crecimiento debe enfrentar.

El cuarto capítulo trata sobre la construcción de hospitales, política prioritaria del peronismo. Entre 1946 y 1949 Carrillo duplica el número de camas mediante la construcción

(1) Estudiante Master Historia. Escuela de Altos Estudios en Ciencias Sociales, Paris 5 rue Rene Miston. 93400 Saint Ouen - Paris. Francia. diegoortuzar@hotmail.com 
de hospitales, situación que hacia 1950 se estanca a raíz de las reducciones presupuestarias del Ministerio de Salud. En forma paralela, la Fundación Eva Perón aumenta su injerencia en obras sociales de carácter sanitario, con un presupuesto en aumento que termina por opacar la gestión de Carrillo como ministro de salud. La autora da cuenta además de las tensiones entre dicha Fundación y el Ministerio, señalando las diferentes lógicas que justificaban sus intervenciones.

El quinto y último capítulo aborda las campañas sanitarias del peronismo. La integración regional, la propagación de hábitos saludables y el control de brotes epidémicos fueron los principales objetivos de la implementación de charlas, propagandas, publicaciones, obras de teatro, e incluso caravanas sanitarias y travesías en tren para distribuir prestaciones sanitarias en todo el territorio.

Especial interés presenta la problemática alimenticia a propósito de la crisis económica. La autora relata los intentos de Carrillo, a cargo de un desfinanciado Ministerio, de mejorar la dieta nacional mediante innovaciones que Perón termina calificando como un fracaso. Paralelamente se pacta un giro político con los gremios empresariales, y la Fundación Eva Perón consolida su rol en atención sanitaria y construcción de policlínicos.

El libro de Ramacciotti cuenta con una extensa revisión de archivos gubernamentales y de prensa, además de entrevistas y publicaciones de diversa índole. La escritura privilegia más la forma temática que la cronológica, y el apoyo de imágenes de archivo enriquece la lectura de los procesos de estatización descritos. La organización temática es especialmente interesante por cuanto desarrolla en forma simultánea la centralización gubernamental, la institucionalización de la salud, la expansión hospitalaria y la masificación de la política sanitaria. Dichos paralelismos evidencian la puesta en marcha de regulaciones simultáneas y heterogéneas sobre la población, que intervienen a la vez que producen un cuerpo nacional a través de campañas, bioestadísticas y hospitales.

Sin embargo, dicha biopolítica ocurre en distintas modalidades según la incidencia o indiferencia de organismos sanitarios, produciendo precariedad en algunos sectores a la vez que protección y resguardo en otros. Allí se ubica el compromiso logrado de la autora, que mediante un recorrido histórico devela los pilares de una política que distribuye en forma desigual e injusta los servicios sanitarios en Argentina. 